\title{
ATMOSPHERIC $\mathrm{H}_{2} \mathrm{O}_{2}$ FIELD MEASUREMENTS IN A TROPICAL ENVIRONMENT: BAHIA, BRAZIL
}

\author{
P. Jacob, T. M. Tavares, ${ }^{*}$ V. C. Rocha* and D. Klockow \\ Institute of Spectrochemistry and Applied Spectroscopy (ISAS) P.O. Box 1013 52, D-4600 Dortmund 1, \\ F.R.G. and *Instituto de Química, Universidade Federal da Bahia (UFBa) Campus Universitário da \\ Federaçao s/n, 40210 Salvador, Ba, Brazil
}

(First received 10 May 1989 and in final form 22 August 1989)

\begin{abstract}
Concentrations of $\mathrm{H}_{2} \mathrm{O}_{2}$ in atmospheric gas and liquid phases were determined for the first time in the tropical Southern Hemisphere. Measurements were carried out in the Salvador area, Bahia, $13^{\circ} \mathrm{S}$, $38^{\circ} \mathrm{W}$ ) both at the seaside and $500 \mathrm{~m}$ away from it as well as at $270 \mathrm{~km}$ inland, in a rural area, during March-April 1988. Gaseous $\mathrm{H}_{2} \mathrm{O}_{2}$ was collected by cryogenic and rain by wet only sampling. Analyses were performed with the peroxyoxalate chemiluminescence method, employing a compact field apparatus. The measured gas phase concentrations ranged from 0.2 to $3.9 \mathrm{ppbv}$ compared to $0.01-0.6 \mathrm{ppbv}$ obtained from measurements with similar methodology in Dortmund $\left(51^{\circ} 30^{\prime} \mathrm{N}, 7^{\circ} 30^{\prime} \mathrm{E}\right)$, F.R.G, during summer. The corresponding concentration ranges in rainwater are 0.9-6.8 ppmw (Bahia) and 0.1-2.2 ppmw (Dortmund, summertime). Gas/liquid $\mathrm{H}_{2} \mathrm{O}_{2}$ equilibrium during rain events is only attained at precipitation rates below $1 \mathrm{~mm} \mathrm{~h}^{-1}$
\end{abstract}

Key word index: Hydrogen peroxide, cryo sampling, tropical environment, gas/liquid distribution.

\section{INTRODUCTION}

The knowledge of atmospheric $\mathrm{H}_{2} \mathrm{O}_{2}$ levels in different parts of the globe is of great interest due to the following reasons.

First, gaseous $\mathrm{H}_{2} \mathrm{O}_{2}$ is involved with the gas phase radical chemistry, acting as a sink for $\mathrm{HO}_{2}$ (Schwartz, 1984) and, by photolysis, as a source of OH (Chameides and Davis, 1982; McElroy, 1986). These radicals are the most important oxidizing species for the transformation of atmospheric pollutants (Hewitt and Harrison, 1985).

Second, as $\mathrm{H}_{2} \mathrm{O}_{2}$ is extremely soluble in water, the atmospheric liquid phase (such as cloud and fog droplets, rain and dew) is the most important sink for $\mathrm{H}_{2} \mathrm{O}_{2}$. In addition in acidic liquid phase, $\mathrm{H}_{2} \mathrm{O}_{2}$ is the major oxidizing agent for $\mathrm{S}(\mathrm{IV})$, transforming $\mathrm{SO}_{3}^{2-}$ into $\mathrm{SO}_{4}^{2-}$ (Hoffmann and Edwards, 1975; Penkett et al., 1979; Möller, 1980; Martin and Damschen, 1981; Kunen et al., 1983; McArdle and Hoffmann, 1983), and also for $\mathrm{NO}_{2}^{-}$(Damschen and Martin, 1983; Lee and Lind, 1986).

Third, model calculations used for estimations and predictions of conversion rates of airborne matter call for cognizance of $\mathrm{H}_{2} \mathrm{O}_{2}$ levels in distinct environments and distribution between the different phases (Logan et al., 1981; Thompson and Cicerone, 1982; Adewuyi et al., 1984; Graedel and Goldberg, 1983).

A number of investigations have been carried out in the Northern Hemisphere (Farmer and Dawson, 1982; Römer et al., 1985; Slemr et al., 1986; Jacob et al., 1986; Heikes et al., 1987; Keuken et al., 1988). Even natural background levels, traced back to 100,000 years, have been reported in deposited snow of the Arctic and
Antarctic regions (Neftel et al., 1984, 1986). From the predicted atmospheric behavior of $\mathrm{H}_{2} \mathrm{O}_{2}$ and the seasonal and diurnal variations of $\mathrm{H}_{2} \mathrm{O}_{2}$ concentrations found, both in liquid (Yoshizumi et al., 1984) and in gas phase (Heikes et al., 1987), it may be concluded that high solar irradiation and low anthropogenic emissions lead to high $\mathrm{H}_{2} \mathrm{O}_{2}$ concentrations. Therefore unpolluted tropical areas should be the greatest sources of atmospheric $\mathrm{H}_{2} \mathrm{O}_{2}$.

To the best of our knowledge no data for atmospheric $\mathrm{H}_{2} \mathrm{O}_{2}$ in the Southern Hemisphere are available. For this reason $\mathrm{H}_{2} \mathrm{O}_{2}$, in the gas (ambient air) as well as in the liquid (rain) phase, has been determined at three locations of the state of Bahia, Northeast Brazil, at different distances from the seaside and different levels of anthropogenic activities. Additionally distribution between liquid and gaseous phase during rain events has been studied.

\section{EXPERIMENTAL}

Sequential gas samples with approximately $1 \mathrm{~h}$ time resolution and fractioned rain samples with 3-7 min resolution for showers and around $1 \mathrm{~h}$ for light rain were collected during March-April 1988 in the state of Bahia at the following sites: Salvador ( $\sim 1.8$ million inhabitants), at the Campus of the Federal University of Bahia $\left(13^{\circ} 0.5^{\prime} \mathrm{S}, 38^{\circ}\right.$ $31^{\prime} \mathrm{W}, 500 \mathrm{~m}$ from seaside, $100 \mathrm{~m}$ above sea level); Itaparica Island, at Ponta da Cruz $\left(13^{\circ} 4^{\prime} \mathrm{S}, 38^{\circ} 42^{\prime} \mathrm{W}\right)$ at the seaside, and $270 \mathrm{~km}$ inland, in Mucuge $\left(13^{\circ} \mathrm{S}, 41^{\circ} \mathrm{W}\right)$, at the Paraguaçu River bank.

Gaseous samples were taken by a cryogenic technique (Jacob et al., 1986) at $1.0-1.5 \mathrm{~m}$ above ground using a flow rate of only $470 \mathrm{f} \mathrm{h}^{-1}$ to assure $-45^{\circ} \mathrm{C}$ at all times in the cooler, since sampled air temperatures varied around $30^{\circ} \mathrm{C}$. 
During the sampling period r.h. and temperature were always registered in order to make possible the calculation of the absolute water vapor content of the air under study. Under these operational conditions and local r.h. most of the time above $80 \%$, collection of ambient water vapor reached a rate of about $10 \mathrm{ml} \mathrm{h}^{-1}$, thus allowing even greater time resolution than indicated. By the method employed $\mathrm{H}_{2} \mathrm{O}_{2}$ concentrations can be directly related to the water vapor content of air without taking into account collection efficiency (Jacob et al., 1986). Rainwater was collected with a borosilicate glass funnel $(26 \mathrm{~cm}$ diameter) in polypropylene vessels. Precipitation rate was determined by weighing the total water amount sampled within a certain time period.

Hydrogen peroxide determinations in the condensate were carried out immediately in the field by a chemiluminescence technique using bis-(2,4,6-trichlorophenyl)oxalate (TCPO) as a reagent, perylene as a sensitizer, and acetone as a solvent. The method described elsewhere (Klockow and Jacob, 1986) was used with the following modifications for higher reproducibility: TCPO and perylene concentrations were $1 / 3$ that of the original methodology. The borate buffer concentration could be lowered from 0.1 to $0.08 \mathrm{M}$ since the $\mathrm{pH}$ values of the collected rain were high and varied around 6 . A compact $5 \mathrm{~kg}$ field version of the original chemiluminescence equipment was employed (Jacob, 1987). It consists of a photomultiplier (Hamamatsu, R 268) and a multiplier socket (Dr Seitner, M 1030 FK-E) with high voltage power supply, amplifier, electronic damping and zero shifting. The photocurrent, proportional to the light intensity emitted from the flow cell, was registered by a $12 \mathrm{~V}$ recorder (Siber Kikei, SS $100 \mathrm{f}$. The flow cell is part of a flow injection system built up with a peristaltic pump (Ismatec, mini S-280), low pressure injection valve (Rheodyne, no. 5020), and $500 \mu l$ sample loop.

The expected limit of detection of the TCPO analytical method is $0.3 \mathrm{ppbw} \mathrm{H}_{2} \mathrm{O}_{2}$ and the limit of determination of the overall methodology (sampling included) varies between 0.2 and 6 pptv $\mathrm{H}_{2} \mathrm{O}_{2}$, depending on the water vapor content of ambient air (Jacob et al., 1986). As $\mathrm{H}_{2} \mathrm{O}_{2}$ concentrations in Bahia are high, acetone purification was not pursued to its complete possibilities, resulting in higher blanks and therefore higher detection limits. In this study the detection limit for rain water was $1.6 \mathrm{ppbw}$ of $\mathrm{H}_{2} \mathrm{O}_{2}$ and the range of determination limit for gaseous $\mathrm{H}_{2} \mathrm{O}_{2} 18-29$ pptv.

In a few cases the water collected in the cryogenic trap was not only analyzed for its $\mathrm{H}_{2} \mathrm{O}_{2}$ content but also for aerosol particle constituents such as $\mathrm{Cl}^{-}, \mathrm{NO}_{3}^{-}, \mathrm{SO}_{4}^{2-}$ and $\mathrm{Na}^{+}$. The results indicated that some particulate matter, especially sea spray components, was deposited at the ice layer covering the walls of the collection tube. This is, however, only a small fraction of total suspended particulate matter (Jacob et al., 1986 ) and is not assumed to cause significant interference in $\mathrm{H}_{2} \mathrm{O}_{2}$ determination.

A co-condensation of $\mathrm{SO}_{2}$ along with $\mathrm{H}_{2} \mathrm{O}_{2}$ and water vapor could reduce the amount of $\mathrm{H}_{2} \mathrm{O}_{2}$ present in solution after melting of the ice in the collection tube. Such an interference, however, is not of major importance for the present study, since $\mathrm{SO}_{2}$ concentrations in Salvador are below $1 \mathrm{ppbv}$, and only about $0.1 \%$ of $\mathrm{SO}_{2}$ pumped through the cryo trap is collected in the ice phase (Jacob, 1988).

\section{RESULTS AND DISCUSSION}

The $\mathrm{H}_{2} \mathrm{O}_{2}$ mixing ratios at the three sites in Bahia, Brazil, are presented in Table 1, along with those at Dortmund, F.R.G., obtained with the same methodology in summertime. Average levels of Bahia are 12-20 fold the ones of Dortmund. One reason for this difference is the increasing radiation intensity and higher humidity with lower latitude which leads to higher $\mathrm{H}_{2} \mathrm{O}_{2}$ formation rates. This has been shown from aircraft measurements by Heikes et al. (1987) and Van Valin et al. (1987). The latter, based on their results obtained between $40^{\circ}$ and $28^{\circ} \mathrm{N}\left(91^{\circ} 30^{\prime} \mathrm{W}\right)$ at about $2000 \mathrm{msl}$, estimated a concentration gradient of $0.05 \mathrm{ppbv}$ per degree latitude. Indeed, the difference in average atmospheric gaseous $\mathrm{H}_{2} \mathrm{O}_{2}$ level between the two site regions (Bahia, Brazil and F.R.G.) is compatible with this estimation. Another reason for lower $\mathrm{H}_{2} \mathrm{O}_{2}$ gas phase concentrations at Dortmund most probably are the higher $\mathrm{NO}_{x}$ mixing ratios, which suppress $\mathrm{H}_{2} \mathrm{O}_{2}$ formation, and higher $\mathrm{SO}_{2}$ loads, which deplete $\mathrm{H}_{2} \mathrm{O}_{2}$ in the atmospheric liquid phase. Additionally, the ethanol used as vehicle fuel in Brazil results in aldehyde, especially acetaldehyde, emissions (Grosjean et al., 1990), and aldehydes establish an atmospheric route for $\mathrm{H}_{2} \mathrm{O}_{2}$ production (Seinfeld, 1986).

Whether differences in the concentrations of $\mathrm{NO}_{x}$ or $\mathrm{SO}_{2}$ are responsible for the different $\mathrm{H}_{2} \mathrm{O}_{2}$ levels observed at the three sampling sites of Bahia, especially those at Salvador and at the site in the interior (background conditions), cannot be proved, since no data for these pollutants are available for all sites. Conclusions on the possible contribution of aldehyde emissions to $\mathrm{H}_{2} \mathrm{O}_{2}$ formation in the urban area cannot be drawn from the available results, since $\mathrm{H}_{2} \mathrm{O}_{2}$ levels are generally higher in the interior than in Salvador.

The averaged diurnal concentration variations of gas phase $\mathrm{H}_{2} \mathrm{O}_{2}$ at the four sites are illustrated in Fig. 1. Daytime maxima on clear days appear at about $14.00 \mathrm{~h}$ in Salvador and at the interior site, and at 18:00 to $19: 00 \mathrm{~h}$ at Dortmund in summer. Similar summer diurnal variations have been reported by Heikes et al. (1987) from measurements at Whiteface Mountain, New York, with maxima around 18:00 h. Attention should be called for the fact, that in March daytime in Bahia starts at 5:30 h and ends at 18:00 h (local time), while during summer at Dortmund day-

Table 1. $\mathrm{H}_{2} \mathrm{O}_{2}$ mixing ratios at different locations of Bahia, Brazil and one site at Dortmund, F.R.G.

\begin{tabular}{lccccc}
\hline Site & $\begin{array}{c}\text { Period } \\
(1988)\end{array}$ & $\begin{array}{c}\text { Number of measured } \\
\text { diurnal variations }\end{array}$ & Maximum & $\begin{array}{c}\mathrm{H}_{2} \mathrm{O}_{2}(\mathrm{ppbv}) \\
\text { Minimum }\end{array}$ & $\begin{array}{c}\text { Daytime } \\
\text { average }\end{array}$ \\
\hline Salvador & $3.3-17.3$ & 10 & 2.3 & 0.20 & 0.90 \\
Itaparica & $29.3-4.4$ & 5 & 2.4 & 0.23 & 1.10 \\
Interior & $19.3-25.3$ & 5 & 3.9 & 0.42 & 1.50 \\
Dortmund, & Summers & 10 & 0.54 & 0.01 & 0.07 \\
F.R.G. & 1985,1986 & & & & \\
\hline
\end{tabular}




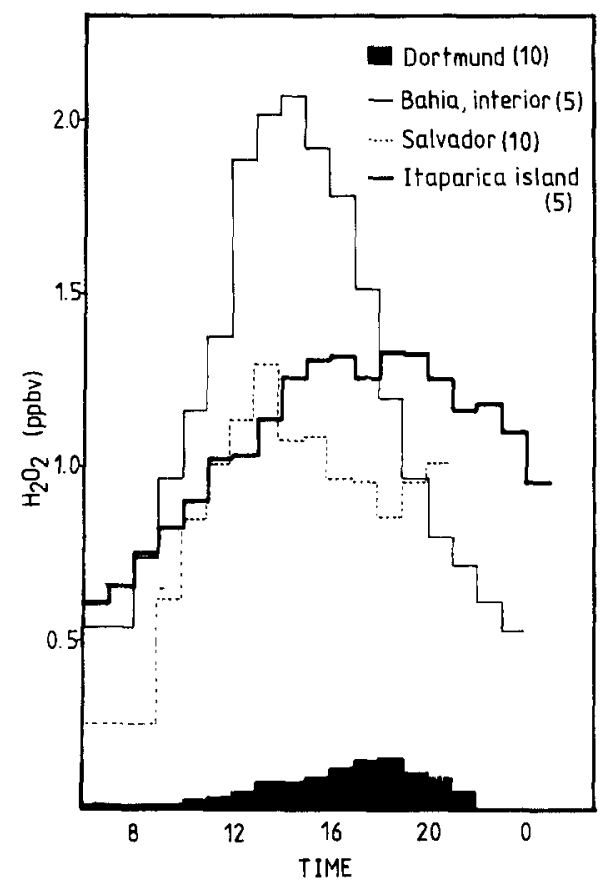

Fig. 1. Averaged diurnal variation of $\mathrm{H}_{2} \mathrm{O}_{2}$ gas phase mixing ratio at different sites in Bahia, Brazil and one site at Dortmund, F.R.G. (number of measured diurnal variations in parentheses).

time is from about $5: 00 \mathrm{~h}$ to $21: 30$ (local time). The unexpected late afternoon-early evening averaged maxima of Itaparica can only be explained by the repeated morning-early afternoon cloudiness during the study period.

In Dortmund the appearance of clouds leads to a significant decrease in $\mathrm{H}_{2} \mathrm{O}_{2}$ gas phase levels (Jacob et $a l ., 1987)$. This has been attributed to an uptake of gaseous $\mathrm{H}_{2} \mathrm{O}_{2}$ by cloud water droplets and subsequent reaction with S(IV) (Penkett et al., 1979), as modeled by Carmichael et al. (1986). This behavior should be less striking in Bahia, where a distinct excess of $\mathrm{H}_{2} \mathrm{O}_{2}$ over S(IV) exists, and gas liquid water equilibrium is not affected by other side reactions. The clouds arriving at the coast of Bahia are formed over the Atlantic Ocean and presumably are 'clean'. In fact the presence of clouds leads to lower gaseous $\mathrm{H}_{2} \mathrm{O}_{2}$ levels when compared to equivalent sunny clear time periods. However, the arrival of individual, low, fast moving, raining cumulus clouds resulted in an increase in $\mathrm{H}_{2} \mathrm{O}_{2}$ mixing ratios prior to the sharp decrease at the onset of rainfall at the sampling site. As rain stopped and the cumulus clouds were moving away, a sharp increase in gaseous $\mathrm{H}_{2} \mathrm{O}_{2}$ concentration occurred. This phenomenon of 'before cumulus' and 'after cumulus' enlargement of $\mathrm{H}_{2} \mathrm{O}_{2}$ mixing ratio might be related to cloud droplet evaporation at cloud edges and subsequent release of dissolved $\mathrm{H}_{2} \mathrm{O}_{2}$.

Rainwater $\mathrm{H}_{2} \mathrm{O}_{2}$ concentrations in tropical Bahia are obviously higher than those in temperate zones, as can be seen in Table 2. However, due to strong variations in rainfall rate and pattern, a general comparison is difficult to be made. Figures $2 \mathrm{a}$ and $2 \mathrm{~b}$ show that lower precipitation rates lead to higher $\mathrm{H}_{2} \mathrm{O}_{2}$ concentrations in rain, with a linear correlation over a certain range. A correlation between gas phase and liquid phase $\mathrm{H}_{2} \mathrm{O}_{2}$ concentration was established at different precipitation rates (Fig. 3), based on simultaneous measurements of $\mathrm{H}_{2} \mathrm{O}_{2}$ concentrations in ambient air and in rain water. During low rate precipitation the correlation seems to obey Henry's Law, whereas during heavy showers no equilibrium could be observed.

From several such field investigations Henry's Law constants for different ambient temperatures were obtained and ranged between $1.3 \times 10^{5}$ at $20^{\circ} \mathrm{C}$ and $0.7 \times 10^{5} \mathrm{M} \mathrm{atm}^{-1}$ at $32^{\circ} \mathrm{C}$. These values are somewhat higher than those determined by other authors (Hwang and Dasgupta, 1986; Lazrus et al., 1986; Martin and Damschen, 1981; Yoshizumi et al., 1984) through laboratory experiments.

Results from three other events are shown in Fig. 4. Here the measured $\mathrm{H}_{2} \mathrm{O}_{2}$ concentration in rain is compared to a calculated equilibrium concentration in rain derived from measured gas phase mixing ratios and Henry's Law constant (Martin and Damschen, 1981). It can be seen that the differences between measured and calculated concentration decrease with decreasing rainfall rate $\bar{R}$.

Hydrogen peroxide concentrations in gas and liquid phases were measured simultaneously several times. Results obtained during a typical rain event have been plotted in Fig. 5 along with the precipitation rate. At the beginning and at the end of the event the precipitation rate was lower, favouring

Table 2. $\mathrm{H}_{2} \mathrm{O}_{2}$ concentrations in rainwater at different locations of Bahia, Brazil and one site at Dortmund, F.R.G.

\begin{tabular}{lccccc}
\hline \multirow{2}{*}{ Site } & Date & Time & Minimum & Maximum & Average \\
\hline Salvador & 9.03 .88 & $12.40-16.30$ & $2.9(85)$ & $6.8(200)$ & $4.2(124)$ \\
& 11.03 .88 & $12.20-14.30$ & $0.64(19)$ & $3.9(115)$ & $1.0(29)$ \\
Itaparica & 29.03 .88 & $12.47-13.30$ & $0.95(28)$ & $1.7(50)$ & $1.3(38)$ \\
Interior & 23.03 .88 & $13.50-13.58$ & $0.82(24)$ & $1.1(32)$ & $0.95(28)$ \\
& 24.03 .88 & $16.15-16.30$ & $4.0(118)$ & $5.7(168)$ & $4.8(141)$ \\
Dortmund & Summers & Daytime & $0.1(2.9)$ & $2.2(65)$ & $0.3(8.8)$ \\
& 1985,1986 & & & & \\
\hline
\end{tabular}




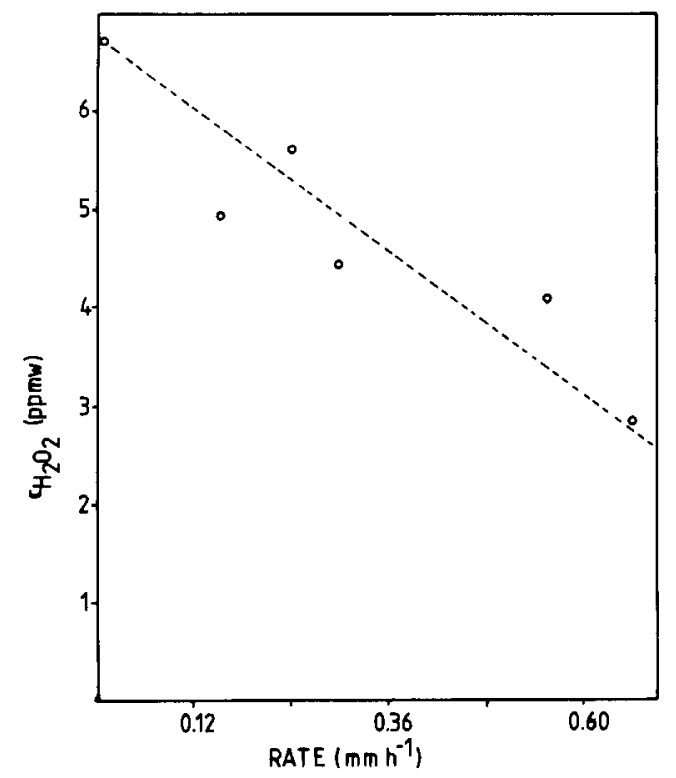

Fig. 2a. $\mathrm{H}_{2} \mathrm{O}_{2}$ concentrations in rainwater as a function of precipitation rate, Salvador/Bahia; low precipitation rates.

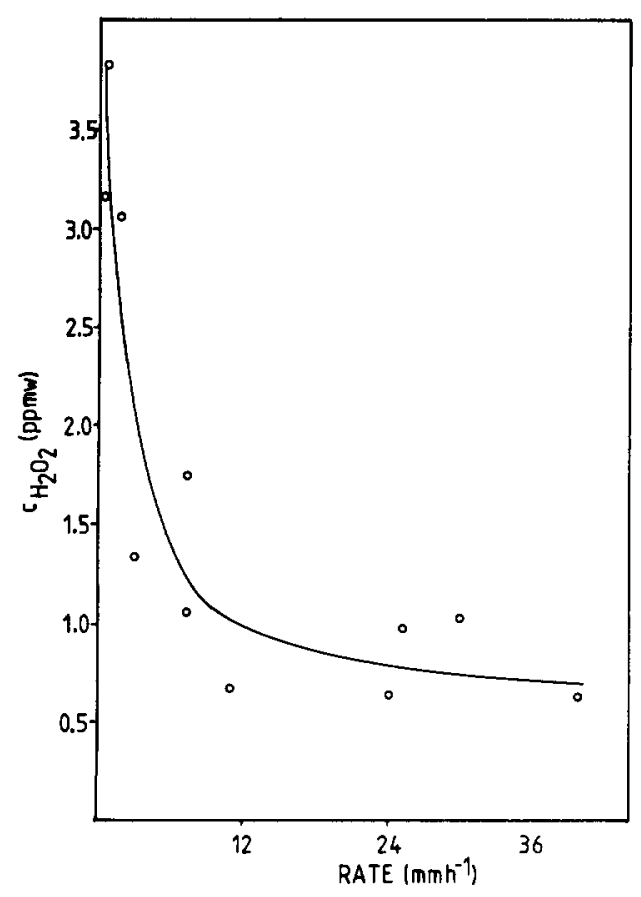

Fig. 2b. $\mathrm{H}_{2} \mathrm{O}_{2}$ concentrations in rainwater as a function of precipitation rate, Salvador/Bahia; low to high precipitation rates.

scavenging of gaseous $\mathrm{H}_{2} \mathrm{O}_{2}$. At higher precipitation rates lower $\mathrm{H}_{2} \mathrm{O}_{2}$ concentrations were found in the liquid phase. During the rainy period no significant change was observed in the $\mathrm{H}_{2} \mathrm{O}_{2}$ gas phase concentration. This means that either a constant input of

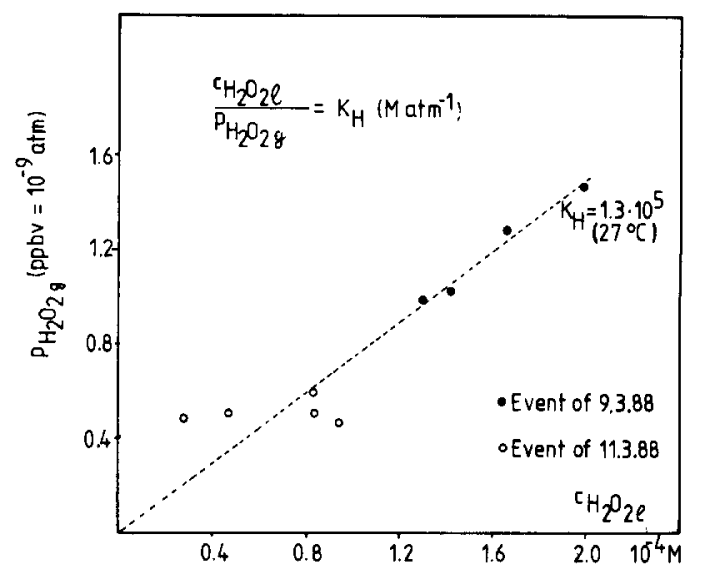

Fig. 3. Correlation between atmospheric $\mathrm{H}_{2} \mathrm{O}_{2}$ gas and liquid phase concentrations.

gaseous $\mathrm{H}_{2} \mathrm{O}_{2}$ from an unknown source existed or that an efficient mixing of air masses took place. This last possibility is most likely since the rain events investigated were always accompanied by winds of $\sim 5 \mathrm{~m} \mathrm{~s}^{-1}$.

\section{CONCLUSIONS}

Cryo sampling is a suitable technique for collection of gas phase $\mathrm{H}_{2} \mathrm{O}_{2}$ in humid tropical environments, offering sufficient time resolution. Intercalibration exercises are however desirable. The TCPO chemiluminescence field equipment is appropriate for in situ measurements offering much lower detection limits than necessary for not heavily polluted areas in the tropics.

Average gas phase $\mathrm{H}_{2} \mathrm{O}_{2}$ levels in Bahia are 12-20 times greater than those measured with the same methodology at Dortmund, F.R.G., in summertime. Concentration maxima on clear days in Bahia are found between 12:00 and 16:00 h, whereas in F.R.G., in summertime, they appear between 18:00 and 19:00 h. Gaseous $\mathrm{H}_{2} \mathrm{O}_{2}$ levels are lower in presence of clouds. However, the coming in of raining cumulus clouds increased temporarily the $\mathrm{H}_{2} \mathrm{O}_{2}$ mixing ratios. Rainfall generally lowered the $\mathrm{H}_{2} \mathrm{O}_{2}$ gas phase concentrations.

Great variations in $\mathrm{H}_{2} \mathrm{O}_{2}$ liquid phase concentrations were found during different rain events and could be correlated with rain fall rate. Gas/liquid equilibrium for $\mathrm{H}_{2} \mathrm{O}_{2}$ during rain events was only attained when the precipitation rate was below $1 \mathrm{~mm} \mathrm{~h}^{-1}$.

To complete the still tentative scenario, further $\mathrm{H}_{2} \mathrm{O}_{2}$ measurements in the tropics are needed, not only in other types of area, such as forests, plantations or heavily polluted areas, but also in other atmospheric phase systems such as fog, dew, clouds, sea spray etc. 

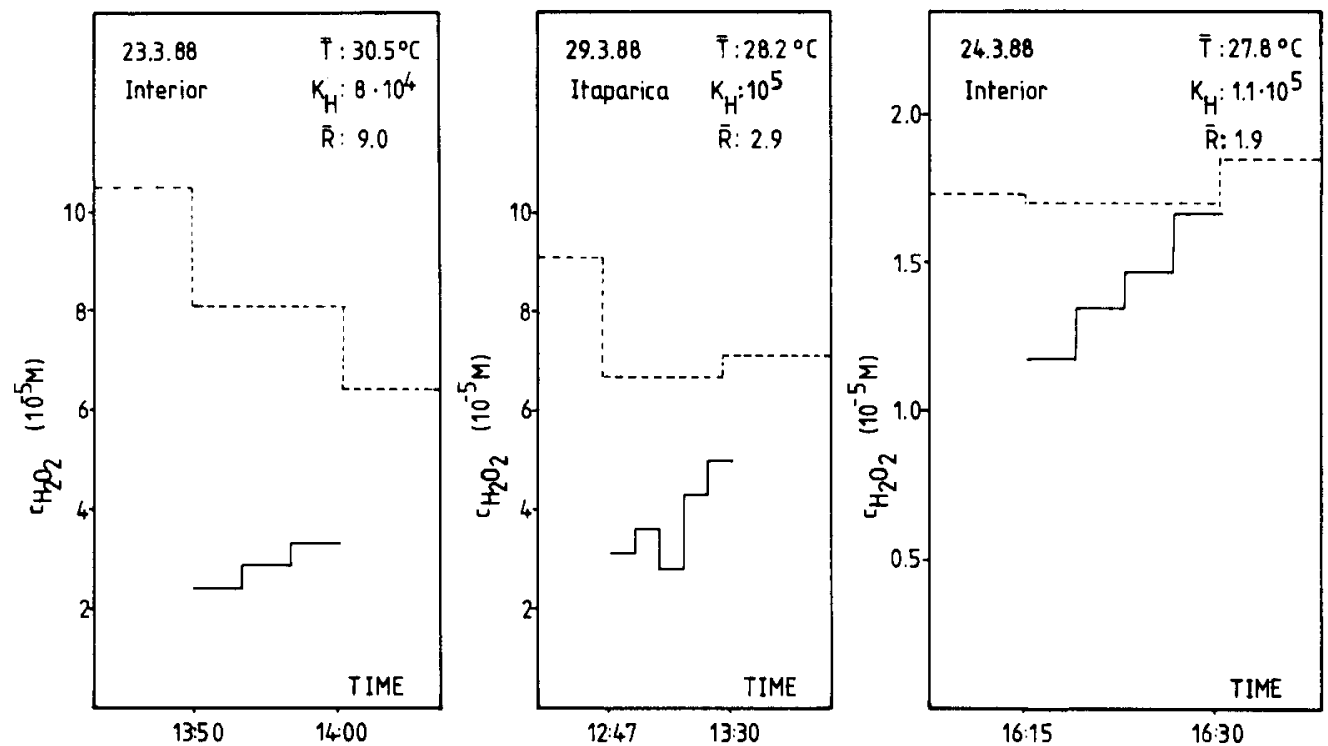

Fig. 4. Measured (-) and calculated (..-) equilibrium $\mathrm{H}_{2} \mathrm{O}_{2}$ concentrations in rainwater during different events; $T$ : average air temperature, $K_{\mathrm{H}}$ : Henry's Law constant $\left(\mathrm{M} \mathrm{atm}^{-1}\right), \bar{R}$ : average precipitation rate $\left(\mathrm{mm} \mathrm{h}^{-1}\right)$.

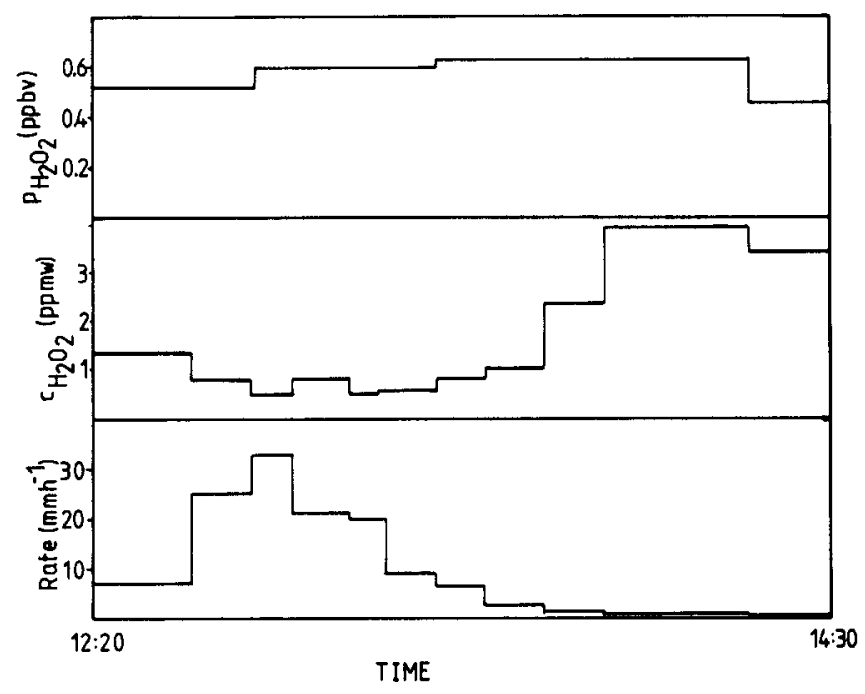

Fig. 5. Gas and liquid phase $\mathrm{H}_{2} \mathrm{O}_{2}$ concentrations and rainfall rate during a precipitation event on 11 March 1988, at Salvador/Bahia.

Acknowledgements-We are in debt with GTZ (German Association for Technical Cooperation) for the donation of equipment to the research group of UFBa, to Stiftung Volkswagenwerk for support of additional material and scientists exchange between Germany and Brazil, to $\mathrm{CNPq}$ and COMCITEC for covering of local costs and to Mr Nelson Taboada for financing and making possible the sampling at Mucugé site.

\section{REFERENCES}

Adewuyi Y. G., Cho S. Y., Tsay R. P. and Carmichael G. R. (1984) Importance of formaldehyde in cloud chemistry. Atmospheric Environment 18, 2413-2420.
Carmichael G. R., Peters L. K. and Kitada T. (1986) A second generation model for regional-scale transport/chemistry/ deposition. Atmospheric Environment 20, 173-188.

Chameides W. L. and Davis D. D. (1982) The free radical chemistry of cloud droplets and its impact upon the composition of rain. J. geophys. Res. 87, 4863-4877.

Damschen D. E. and Martin L. R. (1983) Aqueous aerosol oxidation of nitrous acid by $\mathrm{O}_{2}, \mathrm{O}_{3}$ and $\mathrm{H}_{2} \mathrm{O}_{2}$. Atmospheric Environment 17, 2005-2011.

Farmer J. C. and Dawson G. A. (1982) Condensation sampling of soluble atmospheric trace gases. J. geophys. Res. 87, 8931-8942.

Graedel T. E., Farrow L. A. and Weber T. A. (1976) Kinetic studies of the photochemistry of the urban troposphere. Atmospheric Environment 10, 1095-1116.

Graedel T. E. and Goldberg K. I. (1983) Kinetic studies of 
rain drop chemistry-I. Inorganic and organic processes. J. geophys. Res. 88, 10,865-10,882.

Grosjean D., Miguel A. H. and Tavares T. M. (1990) Atmospheric Environment 24B, 101-106.

Heikes B. G., Kok G. L., Walega J. G. and Lazrus A. L. (1987) $\mathrm{H}_{2} \mathrm{O}_{2}, \mathrm{O}_{3}$ and $\mathrm{SO}_{2}$ measurements in the lower troposphere over the eastern U.S.A. during fall. J. geophys. Res. 92, 915-931.

Hewitt C. N. and Harrison R. M. (1985) Tropospheric concentrations of the hydroxyl radical-a review. Atmospheric Environment 19, 545-554.

Hoffmann M. R. and Edwards J. O. (1975) Kinetics of the oxidation of sulfite by hydrogen peroxide in acid solution. J. phys. Chem. 79, 2096-2098.

Hwang H. and Dasgupta P. K. (1986) Fluorimetric flow injection determination of aqueous peroxides at nanomolar level using membrane reactors. Analyt. Chem. 58, $1521-1524$.

Jacob P., Tavares T. M. and Klockow D. (1986) Methodology for the determination of gaseous hydrogen peroxide in ambient air. Fres. Z. Analyt. Chem. 325, 359-365.

Jacob P. (1987) Wasserstoffperoxid in der atmosphärischen Gas und Flüssigphase: Laborstudien und Felduntersuchungen. Dissertation, Universität Dortmund.

Jacob P., Bambauer A., Tavares T. M. and Klockow D. (1987) Field investigations on the variability of $\mathrm{H}_{2} \mathrm{O}_{2}$ concentration in atmospheric gas phase. In Physico-chemical Behaviour of Atmospheric Pollutants (edited by Angeletti G. and Restelli G.). D. Reidel, Dordrecht.

Jacob P. (1988) Unpublished investigations.

Keuken M. P., Schoonebeek C. A. M., van Wensveen-Louter A. and Slanina J. (1988) Simultaneous sampling of $\mathrm{NH}_{3}$, $\mathrm{HNO}_{3}, \mathrm{HCl}, \mathrm{SO}_{2}$ and $\mathrm{H}_{2} \mathrm{O}_{2}$ in ambient air by a wet annular denuder system. Atmospheric Environment 22, 2541-2548.

Klockow D. and Jacob P. (1986) The peroxyoxalate chemiluminescence and its application to the determination of hydrogen peroxide in precipitation. In Chemistry of Multiphase Atmospheric Systems (edited by Jaeschke W.), pp. 117-130. Springer Verlag, Berlin.

Kunen S. M., Lazrus A. L., Kok G. L. and Heikes B. G. (1983) Aqueous oxidation of $\mathrm{SO}_{2}$ by hydrogen peroxide. J. geophys. Res. 88, 3671-3674.

Lazrus A. L., Kok G. L., Lind J. A., Gitlin J. A., Heikes B. G. and Shetter R. E. (1986) Automated fluorimetric method for hydrogen peroxide in air. Analyt. Chem. 58, 594-597.

Lee Y. N. and Lind J. A. (1986) Kinetic of aqueous-phase oxidation of Nitrogen (III) by hydrogen peroxide. J. geophys. Res. 91, 2793-2800
Logan J. A., Prather M. J., Wofsy S. C. and McElroy M. B. (1981) Tropospheric chemistry: a global perspective. J. geophys. Res. 86, 7210-7254.

Martin L. R. and Damschen D. E. (1981) Aqueous oxidation of $\mathrm{SO}_{2}$ by hydrogen peroxide at low pH. Atmospheric Environment 15, 1615-1621.

McArdle J. V. and Hoffmann M. R. (1983) Kinetic and mechanism of oxidation of aquated sulfur dioxide by hydrogen peroxide at low pH. J. phys. Chem. 87, 5425-5429.

McElroy W. J. (1986) Sources of hydrogen peroxide in cloudwater. Atmospheric Environment 20, 427-438.

Möller D. (1980) Kinetic model of atmospheric $\mathrm{SO}_{2}$ oxidation based on published data. Atmospheric Environment 14, 1067-1076.

Neftel A., Jacob P. and Klockow D. (1984) Measurements of hydrogen peroxide in polar ice samples. Nature 311, 43-45.

Neftel A., Jacob P. and Klockow D. (1986) Long-term record of $\mathrm{H}_{2} \mathrm{O}_{2}$ in polar ice cores. Tellus 38B, 262-270.

Penkett S. A., Jones B. M. R., Brice K. A. and Eggleton A. E. J. (1979) The importance of atmospheric $\mathrm{O}_{3}$ and $\mathrm{H}_{2} \mathrm{O}_{2}$ in oxidizing $\mathrm{SO}_{2}$ in cloud- and rainwater. Atmospheric Environment 13, 123-137.

Römer F. G., Viljeer J. W., van den Beld L., Slangeval H. J., Veldkamp A. A. and Reinders H. F. R. (1985) The chemical composition of clouds and rainwater. Results of preliminary measurements from an aircraft Atmospheric Environment 19, 1847-1858.

Schwartz S. E. (1984) Gas- and aqueous-phase chemistry of $\mathrm{HO}_{2}$ in liquid water clouds. J. geophys. Res. 89, $11,589-11,598$.

Seinfeld J. H. (1986) Atmospheric Chemistry and Physics of Air Pollution, pp. 139-140. John Wiley, New York.

Slemr F., Harris G. W., Hastie D. R., McKay G. I. and Schiff H. I. (1986) Measurements of gas phase hydrogen peroxide in air by tunable diode laser absorption spectroscopy. J. geophys. Res. 91, 5371-5378.

Thompson A. M. and Cicerone R. J. (1982) Clouds and wet removal as causes of variability in trace-gas composition of the marine troposphere. J. geophys. Res. 87, 8811-8826.

Van Valin C. C., Ray J. D., Boatman J. F. and Gunter, R. L. (1987) Hydrogen peroxide in air during winter over the south-central United States. Geophys. Res. Lett. 14, 1146-1149.

Yoshizumi K., Aoki K., Nouchi I., Okita T., Kobayashi T., Kamakura S. and Tajima M. (1984) Measurements of the concentration in rainwater and of the Henry's Law constant of hydrogen peroxide Atmospheric Environment 18, 395-401. 